\title{
THE IMPACTS OF INSTITUTIONAL CAPACITY, INFRASTRUCTURE GOVERNANCE AND EQUITY ON STATE-AND-NATION-BUILDING PROCESSES IN ETHIOPIA
}

\author{
Ambaw Desalegn', Nigussie Solomon ${ }^{2}$ \\ ${ }^{l} \mathrm{PhD}$, Addis Ababa University. College of Law and Governance. Center for Federalism and Governance Studies. Addis \\ Ababa. Ethiopia, Phone No.: +251-911523701. E-mail address: desalegne.ambaw1@gmail.com \\ ${ }^{2}$ PhD, Associate Prof., Dean, Law School. Addis Ababa University. College of Law and Governance. Center for Federalism \\ and Governance Studies. Addis Ababa. Ethiopia, Phone No.: +251-911365365. E-mail address: solnegus@yahoo.com
}

Received 0208 2020; Accepted 04112021

\begin{abstract}
The issue of regional inequity/disparity in infrastructure development has been debated for an effective state-and-nationbuilding processes in the context of Ethiopia. Infrastructure equity process necessitates changes in policies to accommodate new evolving trends and factors. The purpose of the article is to identify the impacts of infrastructure inequity on nationbuilding process including the interrelationships of these constructs/variables. It supports to know the level of (in) equity of public infrastructure growths and its crucial factors in Ethiopia. By analyzing the data (both quantitative and qualitative) gathered, the paper displays that the equity of public infrastructure investments is falling/disrupting and is negatively impacting the nation-building processes in Ethiopia. This is mainly due to the coordination failure of the government. Thus, a unit percentage change of infrastructure equity, for example, would lead to a 59.2\% increment in the nation-building process of Ethiopia taking the remaining effect as a constant.
\end{abstract}

Keywords: Infrastructure Equity, State-and-Nation-building Processes, Ethiopian Regional States.

JEL Codes: D63; H41; H45; P11; R58; L97.

\section{Introduction}

This paper identifies the major issues/problems that could affect infrastructure equity, capacity, governance, and state-andnation-building processes in the context of Ethiopia. Generally, infrastructure shows a central starring role in the country's economic development. For example, a trustworthy basis of energy permits enterprises to implement more capably; a transport network permits producers to transfer goods to end-users (Chotia \& Rao, 2015). In brief, better excellence infrastructure development permits an economy to be more effective, refining its production and nurturing its long-term rate of growth and standards of living (Chotia \& Rao, 2015; Rammelt, 2018) (Rhodes, 2018;). There is general consensus that investment in infrastructure is a dynamic aspect of global growth and its effects reach a profound impact on the larger economy, with its vital and multifaceted implications for social advancement (Chotia \& Rao, 2015; Walter, 2016). Therefore, infrastructure investment and its impacts on, social benefit, sustainability, and economic growth have been given a great deal of consideration today.

Copyright () 2021 Author(s), published by Vytautas Magnus University. This is an open access article distributed under the terms of the Creative Commons Attribution Non-Commercial 4.0 (CC BY-NC 4.0) license, which permits unrestricted use, distribution, and reproduction in any medium provided the original author and source are credited. The material cannot be used for commercial purposes. 
In fact, in the latest years, Ethiopia has been scaling up and extending infrastructure growth, generally via public spending, infrastructure investment gaps are still great, and linking those gaps will need undertaking numerous difficulties, in terms of infrastructure equity, extra project selection, funding, and implementation in Ethiopia (Gurara et al., 2017). Meanwhile, the literature review on the issue of regional equity/disparity in infrastructure development has been debated for some time in the infrastructure sector (Anderson \& O’Neil, 2006; Chotia \& Rao, 2015). Therefore, there are worries about the equity of public investment in infrastructure for an effective nation-building process in Ethiopia.

Moreover, there should be gradually an agreement that infrastructure growth is a multidimensional process that includes connections among diverse goals of improvement and hence would need scientifically considered strategies and policies. It has been also indicated that the policy-making process in Ethiopia lacks the central elements of the process which is not following consultative and systematic way including a top-down approach while an honest bottom-up policy procedure is preferable and possible. The Ethiopian government should deliver a background to guarantee worthy enactment of several performers in carrying out fundamental infrastructure equity's policies and strategies. Hence, planning, strategy, and policy-making processes for equitable infrastructure allocations are a multi-actor processes, fostering advanced institutional capacity and infrastructure governance which harmonizes energies and resources is wellthought-out as one of the determining factors for infrastructure investment.

Lastly, the literature review behind the theoretical and conceptual foundation, the method used for the paper, and the analysis of the variables from the first-hand evidence as well as the policy inferences thereof are offered below.

\section{Literature review}

Building organizational capacity incorporates the main features of three phases which are traditional institutional change, governance, and the micro economics of organizations in developing countries (Bhagavan \& Virgin, 2004). In addition, building capacity for institutional success comprises a number of resources as well as the energy, money, and time to appreciate it through (Act, 2011; Narkhede \& Joshi, 2007). However, several studies showed that less developed countries like Ethiopia have somewhat fragile public infrastructure investment management and administration institutions and that refining those institutions can increase noticeably the equity and effectiveness of public investment (Gurara et al., 2017; Rammelt, 2018). This suggests that "anchor institutions" that can work for as mediators for largely engaging a variety of participants on regional equity accomplishment are serious for raising relations and supporting alterations (Blackwell \& Fox, 2006).

Moreover, vibrant capacity is sketched largely as natural resource potential, gathering of human capital, and institutions that enable inclusive and justifiable economic development (Okoh \& Ebi, 2013; Shiferaw, 2017). Since policymaking and planning for infrastructure investment is a multi-actor processes, fostering a pioneering organizational capacity that organizes resources and energies is reflected as the causes of infrastructure development (Dang \& Pheng, 2015; Okoh \& Ebi, 2013). Nevertheless, there is a lack of organizational capacity of the planning processes of most less developed nations like Vietnam, and Ethiopia as well as the poor interaction between the planning authority and decision-making mechanism of government; insufficiency of communication between political leaders and planners as well as NGO players; ineffectual and introverted public servants; including bureaucratic, and difficult managerial systems (Dang \& Pheng, 2015). 
Management Theory and Studies for Rural Business and Infrastructure Development

eISSN 2345-0355. 2021. Vol. 43. No. 4: 484-499

Article DOI: https://doi.org/10.15544/mts.2021.44

Furthermore, recent issues relating to the capability that national infrastructure organizations in less developed countries are fronting comprise unsuccessful level of equity and competence, and excellence of action; deprived level of entrepreneurship, and professionalism; and, resources scarcities, particularly in building management, knowhow/technology, and finance (Okoh \& Ebi, 2013). Thus, improving the competences/resources of indigenous infrastructure building firms is essential to attaining these growth goals in less developed nations (Hawkins et al., 2008). Accordingly, a fundamental problem that is usually met is the incapability of indigenous "actors" to preserve, reinforce, and make suitable use of prevailing institutional capacity in developing countries (Bhagavan \& Virgin, 2004). These encounters unwavering from the absence of strong considerate around strengthening institutional capacity, slight consideration or dynamism to the framing of strengthening institutional capacity creativities, a lack of suitable support for effective events and varied evidence supporting strengthening institutional capacity outcomes (Act, 2011). Following that, the issues of HRM, organizational/administrative arrangement, organizational engagements and frameworks, and funding infrastructure are considered as institutional capacity factors in Ethiopia.

Regarding infrastructure governance, those countries that are stressed with weak governance, and results in a deficiency of public transparency and accountability including lack of clear rules and regulations, self-governing courts, and well-functioning supervisory plus administrative organizations (OECD, 2015; Oyedele, 2012). The troublesome fact is that governance cracks form the utmost weakness to developing, funding, and executing fundamental physical infrastructure plans for these nations (including road, telecommunication, and electricity) (OECD., 2016; Oyedele, 2012;
Walter, 2016). Making policies and infrastructure planning tells a lack of accountability and transparency, self-governing quality-checks and peer-reviews on predictions and forecasting results by self-regulating evaluation bodies and the professional and scientific community (Ansar et al., 2016; Dang \& Pheng, 2015; Oyedele, 2012). Hence, the intergovernmental collaboration and coordination, decision making process, landacquisition frameworks, and political commitment are considered as factors of infrastructure governance issues in Ethiopia.

More infrastructure investment such as highways will bring countries and neighboring regions nearer to world markets and decrease regional inequity (Zhang \& Fan, 2002). However, investments in infrastructure in less developed countries might get mutual returns, the dissemination of those paybacks could not be overlooked (Castells \& Solé-Ollé, 2005; Rammelt, 2018). One can describe uneven infrastructure development as a market failure. Government intervention may be called upon to address this problem (Schultz, 2017). But, formulating a feasible policy response to uneven economic growth in infrastructure first means properly recognizing the causes of unfair infrastructure development (Schultz, 2017). Therefore, implementing regional equity standards and strategies can map an equitable path for future progress and investment decisionmaking, facilitating to build a country/nation of inclusion and comprehensive opportunity (Blackwell \& Fox, 2006). Present state and home-grown practices endure to reinforce these regional inequities/disparities in developing countries. Specifically, there is high perceptions in infrastructure inequity in Ethiopia, especially in the road, electric, and telecommunication sectors (Kanth \& Geiger, 2017, Unpublished). Then, based on the above general issues, equal opportunity in infrastructure, social/distributive justice, national and regional competitiveness, spatial intervention, and 
citizen/stakeholder/community satisfaction are included as infrastructure fairness factors.

State-and-nation-building denotes an intangible process of emerging a shared sense of identity/community among the numerous groups/regional states making up the people of a specific state (Dinnen, 2006; Linz, 1993; Stepan et al., 2011; Stone \& Hippler, 2005; Von Bogdandy et al., 2005); Hundara, 2017, N/A). Basically, a country stays together when nations share enough standards and favorites and when be able to connect with each other (Alesina \& Reich, 2015); Hundara, 2017, N/A). Thus, worries about failing/fragile states have put state-and-nation-building processes decisively on the policy and academic agenda. This is also of utmost common in non-academic circles, mainly in the donor circles, media, and amongst NGOs (Van de Walle \& Scott, 2009). Most African states have these shared characteristics which are multiethnic; all failed to reestablish and endure their unique African identities; inhibit unfinished state formation; invariably have authoritarian, undemocratic, and ethnocritic governments; practice ethnic-based conflicts and tensions (Fiseha, 2006); Hundara, 2017, N/A). Currently, Ethiopia fully shares these features. Then, based on the above general issues, like rule of law, democratic or public accountability, inclusive growth, and shared national identity is considered as state-andnation-building process factors. This is for the reason that many of the problems facing fragile states arise from both the absence of an operational state and the lack of a shared sense of identity/community among the regional or local population. In addition, state weakness and the comparative lack of nationhood are commonly strengthening circumstances (Dinnen, 2006). Therefore, a convincing response required research and evidence.

Meanwhile, the coordination failure theory offers some significant general instructions for policy makers. This theory/concept often explains the difficulties of market-failure that necessitate careful government involvement to guarantee numerous effects work well together at the same time (Cooper \& John, 1988; Dang \& Pheng, 2015). However, it is stated that coordination failure theory has been complained for its overemphasis on government roles (Cooper \& John, 1988). In other ways, in terms of implications for policy-makers in governments and national organizations, Adams (Adams, 1963) and Anderson and O'Neil (Anderson \& O'Neil, 2006) have identified the need to be committed to the values of equality (equal privileges and prospects) and cohesion (equity and social impartiality). Hence, theory of equity has a number of implications for the federal government practices in infrastructure sector in Ethiopia. Thus, coordination failure, equity, and infrastructure theories served as a theoretical and conceptual foundation for relating growth, equitability of infrastructure, and state-andnation-building processes in this study.

\section{Methodology}

It sought to understand, as completely as possible, the phenomena under study which was infrastructure equity with relation to nationbuilding is a very complex issue (Pandey \& Patnaik, 2014). Both the quantitative and qualitative were used and examined distinctly in this approach. Then, the quantitative outputs were used to design the qualitative issues(Kothari, 1991). One vital area was that the quantitative consequences could not only notify the sampling technique but it could also point toward the kinds of qualitative enquiries to ask respondents in the second phase (Creswell, 2014). Data investigation also encompassed both quantitative (factor investigation) and qualitative (thematic content analysis) methods (Hair Jr et al., 2016; Tavakol \& Dennick, 2011). A questionnaire survey was adapted from different relevant kinds of literature in this paper to discover the key constructs or factors threatening equitable allocation of public infrastructure investments for nation-building by the worried parties (Dang \& Pheng, 2015). Besides, in-depth 
Management Theory and Studies for Rural Business and Infrastructure Development

eISSN 2345-0355. 2021. Vol. 43. No. 4: 484-499

Article DOI: https://doi.org/10.15544/mts.2021.44

interviews, document review, and focus group were the key methods of data gathering used in a qualitative research (CRESWELL, 1998; Hoglund \& Oberg, 2011). Thus, the key informants were also requested to clarify the likely factors that have either positive or negative effects on the impacts of infrastructure equity on the nation-building process (Kaso et al., 2018). These approaches are paired to each other in order to collect information and provided understandings into the present issues and the effects of infrastructure fairness on the state-and-nation-building processes in Ethiopia.

\section{Data Descriptions}

In this paper, descriptive statistics were engaged to analyze the data. Samples of 1037 were selected from the total population of 2688 infrastructure sector's institutions in Ethiopia through "multi-stage stratified random sampling techniques" (Kothari, 1991). The data gathered were coded and entered into the statistical set for the social science (SPSS version 21.0), and used SEM-PLS. The survey was done in January-July
2019 within 4 selected regional states of Ethiopia. Questionnaires were directly sent to federal and regional institutions of Oromia, Amhara, Tigray, and BenshangulGumuz regional states. To triangulate the results, other data was also gathered with international institutions such as the World Bank and UNDP Ethiopia professionals in Addis Ababa. Entirely, 1,037 survey questionnaires were dispersed for the worried respondents and finally, 947 survey questionnaires were collected. Out of this the effective collected response, six engaged responses, and 37 survey questionnaires were wrongly completed. Consequently, a total of 904 complete questionnaires were collected from respondents properly. A representation of $80 \%$ had chosen as a standard for the assessment of a response rate (Fincham, 2008). According to Saldivar(Saldivar, 2012), when a survey is in person, an $80-85 \%$ response rate is worthy. Therefore, the sample is acceptable as important statistical analysis (Hair et al., 2012). Consequently, based on these scholars' surveys, $87 \%$ is a satisfactory response rate for this paper. Data in Table 1 reveal the Questionnaire Return rate.

Table 1. Survey Questionnaire Response Rate

\begin{tabular}{lcccc}
\hline Group & $\begin{array}{c}\text { Questionnaires } \\
\text { distributed }\end{array}$ & $\begin{array}{c}\text { Responses } \\
\text { received }\end{array}$ & $\begin{array}{c}\text { Response } \\
\text { rate }(\boldsymbol{\%})\end{array}$ & $\begin{array}{c}\text { Proportion } \\
(\%)\end{array}$ \\
\hline Federal Government Offices & $\mathbf{2 9 3}$ & $\mathbf{2 6 1}$ & $\mathbf{8 9}$ & $\mathbf{2 9}$ \\
Regional Government Offices & $\mathbf{5 4 1}$ & $\mathbf{4 6 9}$ & $\mathbf{8 7}$ & $\mathbf{5 2}$ \\
Research Institutions & $\mathbf{1 0}$ & $\mathbf{1 0}$ & $\mathbf{1 0 0}$ & $\mathbf{1}$ \\
Civil society and multilateral Organizations & $\mathbf{1 9 3}$ & $\mathbf{1 6 4}$ & $\mathbf{8 5}$ & $\mathbf{1 8}$ \\
Contractors & 129 & 109 & 50 & 3 \\
Consultants & 59 & 3 & $\mathbf{8 0 4}$ & $\mathbf{8 7}$ \\
World Bank Ethiopia & 3 & & $\mathbf{1 0 0}$ \\
UNDP Ethiopia & $\mathbf{1 0 3 7}$ & $\mathbf{9 0 4}$ &
\end{tabular}


Meanwhile, determining the sample size for interviews was difficult. Creswell (CRESWELL, 1998) recommended a sample size from 5 to 25 . By referring to the researchers' experiences, Malterud et al. (Malterud et al., 2016) indicated that a purposive/suitable sample of 6 to 10 participants with varied experiences might, therefore, deliver adequate information. As in-depth interview in this paper typically encompassed explaining with depth and in detail, existing challenges of equity in infrastructure development in Ethiopia and response approach from respondent experiences, nearest to the maximum illustration size that the study scheduled was 23 . 10 purposely selected federal institutions with 10 participants, and 4 institutions (regional president office, road, electric and telecommunication) with 13 participants (Oromia, Amhara, Tigray and Benshangul/Gumuz) with a total of 23 individuals were identified for in-depth interviews. However, only 18 (8 federal and 10 regional) of them decided to be questioned. Thus, the illustration size fulfils the necessary minimum size in in-depth interviews for this paper.

In addition, in-depth interviews, some pertinent Focus Group Discussions (FGDs), and document analysis were involved. Three understandable factors that affected the capacity to design the focus group was ethical issues, budget concerns, and time limitations (Hoglund \& Oberg, 2011; Morgan, 1997). Linking both concrete and practical thoughts helped to elucidate the base for rule of thumb size of the group that indicated range of six to ten (Krueger \& Casey, 2002; Morgan, 1997). It was practically possible for 3 to 6 participants in each focus group due to their different personal reasons. As the FGDs results were more or less similar to the individual interview, one group in each region were adequate for saturation. Then, FGDs were conducted in 4 cities out of 8 (one City in each of four regions: Oromia (Adama), Amhara (Bahir Dar), Tigray (Mekelle), and Benshangul/Gumuz (Assosa)). Moreover, the city administration office was the center of the focus group. Hence, it included the representatives from the road, telecommunication and electric institutions, and advisors, planners, and experts from the administration offices. Some of the participants were also representatives from city councils.

\section{Quantitative Analysis}

Reliability and validity are two central elements in the evaluation of the measurement device(Tavakol \& Dennick, 2011). It is stated that Cronbach's alpha a reliability test (Cronbach, 1951) is the main widely used measures of the reliability test in the organizational and social sciences. Cronbach's alpha is denoted as a measure of internal consistency of the reliability test (Bonett \& Wright, 2015; Tavakol \& Dennick, 2011). Cronbach's alpha was calculated to measure both item-total correlation and/or inter-item correlation. The items are closely related to measure similar behavior, perceptions, and attitude of the respondents. Thus, factor loadings are the correlations and weights between each factor and variable. The greater the load is the more vital in identifying the factor's dimensionality. The loadings plus or minus 0.50 or more are measured basically important. Loadings exceeding plus or minus 0.70 are measured indicators of a definite structure and are the aim of factor analysis (Patel, 2015). From factor loadings which denoted in Table 2, factor shared national identity for state-and-nationbuilding processes, and HRM for institutional capacity have 0.687 and 0.691 respectively. Nevertheless, indicator loadings $>0.5$ items designated a good measurement of the indicator variables. Henceforward, these exceptions are greater than 0.50 which can be measured practically important (Afthanorhan, 2013; Hulland, 1999). Data in Table 2 reveal reliability statistics. 
Management Theory and Studies for Rural Business and Infrastructure Development

eISSN 2345-0355. 2021. Vol. 43. No. 4: 484-499

Article DOI: https://doi.org/10.15544/mts.2021.44

Table 2. Reliability Statistics

\begin{tabular}{|c|c|}
\hline Construct/latent variables & Loadings \\
\hline \multicolumn{2}{|l|}{ Inadequate Institutional capacity of the infrastructure sector in Ethiopia (IC) } \\
\hline Lack of human resource management (HRM) & 0.691 \\
\hline Lack of organizational structure (OS) & 0.846 \\
\hline Lack of organizational systems \& frameworks (OSF) & 0.910 \\
\hline Lack of infrastructure funding (IF) & 0.835 \\
\hline \multicolumn{2}{|l|}{ Lack of infrastructure governance (IG) } \\
\hline Lack of intergovernmental/stakeholders collaboration and coordination (IGR) & 0.866 \\
\hline Lack of decision-making process (DMP) & 0.885 \\
\hline Lack of land acquisition framework/right of way (LAF) & 0.827 \\
\hline Lack of political commitment (PC) & 0.832 \\
\hline \multicolumn{2}{|l|}{ Lack of infrastructure equity in Ethiopia (IE) } \\
\hline Lack of equal opportunity in infrastructure (EO) & 0.814 \\
\hline Lack of social/distributive justice (SJ) & 0.820 \\
\hline Lack of national and regional infrastructure competitiveness (NC) & 0.855 \\
\hline Lack of spatial intervention/planning (SI) & 0.864 \\
\hline Lack of citizen/stakeholder/public satisfaction (CS) & 0.782 \\
\hline \multicolumn{2}{|l|}{ Insufficient nation-building process in Ethiopia (NBP) } \\
\hline Lack of rule of law (RL) & 0.744 \\
\hline Lack of democratic/public accountability (DA) & 0.885 \\
\hline Lack of shared national identity (SNI) & 0.687 \\
\hline Lack of inclusive growth and sustainability (IGS) & 0.841 \\
\hline
\end{tabular}

\section{Reliability Test}

The various constructs and 17 combined indicator factors including 120 items are shown in Table 3 below. Thus, the loadings results are above 0.708 except two indicator variables; i.e., $\mathrm{HRM}=0.691$ and $\mathrm{SNI}=0.686$. The internal consistency of the reliability is usually checked using Cronbach's alpha which are greater than 0.80 for all constructs in this paper. However, the composite reliability $(\mathrm{CR})$ value for each construct/variable must be $\geq 0.60$ (Awang, 2015 ), or $>0.70$ (Hair et al., 2012). Hence, the composite reliability of all constructs/variables is $>0.80$ in this paper; that means factors are reliable. The composite reliability of variablesIC, IG, IE, and NBP are 0.894, 0.914, 0.916, and 0.871 respectively which indicates high levels of reliability and internal consistency. However, the previous study proposes that a cut-off point of 0.60 or more is a prerequisite to validate acceptable composite reliability in explanatory research (Bagozzi \& Yi, 1988) but not beyond 0.95 level (Hair Jr et al., 2014). Thus, the Average Variance Extracted (AVE) value for each construct/variable should be $>0.5$ (Hair et al., 2012). The value for each construct/variable is $>0.5$. Data in Table 3 reavel Major Indicators and Cronbach's Alph. 
Table 3. Major Indicators and Cronbach's Alpha

\begin{tabular}{|c|c|c|c|c|c|c|c|c|c|}
\hline $\begin{array}{l}\text { Latent } \\
\text { variables }\end{array}$ & $\begin{array}{l}\text { Major } \\
\text { Indicators }\end{array}$ & $\begin{array}{l}\text { No of } \\
\text { Items }\end{array}$ & $\begin{array}{l}\text { Items } \\
\text { above } \\
0.5\end{array}$ & $\begin{array}{l}\text { Items } \\
\text { above } \\
0.6\end{array}$ & $\begin{array}{l}\text { Factor } \\
\text { Loadings }\end{array}$ & $\begin{array}{l}\text { Cronbach's } \\
\text { Alpha }\end{array}$ & rho_a & CR & AVE \\
\hline \multirow[t]{4}{*}{ IC } & HRM & 8 & 3 & 2 & 0.691 & 0.841 & 0.867 & 0.894 & 0.68 \\
\hline & OS & 6 & 6 & 6 & 0.846 & & & & \\
\hline & OSF & 10 & 10 & 10 & 0.910 & & & & \\
\hline & IF & 8 & 5 & 4 & 0.835 & & & & \\
\hline \multirow[t]{4}{*}{ IG } & IGR & 7 & 7 & 7 & 0.866 & 0.875 & 0.876 & 0.914 & 0.728 \\
\hline & DMP & 5 & 5 & 5 & 0.885 & & & & \\
\hline & LAF & 6 & 6 & 6 & 0.827 & & & & \\
\hline & PC & 7 & 7 & 4 & 0.832 & & & & \\
\hline \multirow[t]{5}{*}{ IE } & EO & 6 & 6 & 4 & 0.812 & 0.885 & 0.888 & 0.916 & 0.685 \\
\hline & SJ & 8 & 7 & 3 & 0.820 & & & & \\
\hline & $\mathrm{NC}$ & 8 & 7 & 6 & 0.854 & & & & \\
\hline & SI & 8 & 7 & 7 & 0.865 & & & & \\
\hline & CS & 6 & 6 & 5 & 0.784 & & & & \\
\hline \multirow[t]{4}{*}{ NBP } & RL & 8 & 5 & 4 & 0.750 & 0.801 & 0.823 & 0.871 & 0.629 \\
\hline & DA & 7 & 7 & 7 & 0.883 & & & & \\
\hline & SNI & 6 & 4 & 0 & 0.686 & & & & \\
\hline & IGS & 6 & 6 & 6 & 0.839 & & & & \\
\hline
\end{tabular}

(Source: Own data, 2019)

\section{Validity Test}

Establishing the validity of measures was the other focus of the study (Mertens, 2015). In order to confirm the quality of this paper, content validity of instruments of the study was checked. Eleven senior subject-matter experts had participated. The content validity was also verified by the advisors, who looked into the relevancy of the questions and the scales of measurement. Moreover, for convergent validity (CV) and construct reliability, the AVE value for latent IC, IG, IE, and NBP is above 0.50. Besides, discriminant validity (DV) is satisfied with all the measured criteria for the reason that the square root of AVE of IC, IG, IE, and NBP are greater than the corresponding latent variable/construct correlations. Then, DV is met as the square root of AVE > Latent Variable Constructs.

\section{Factor Interpretation}

The paper revealed the most significant constructs that critically impacts the equitable allocation of infrastructure across regional states in Ethiopia. The graphical reperesentation of the following figure depicts the impacts and processes how the lack of capacity, governance, and infrastructure equity including other factors considered in this study have negatively impaced state-and-nation-building processes in the country. See Figure 1. 


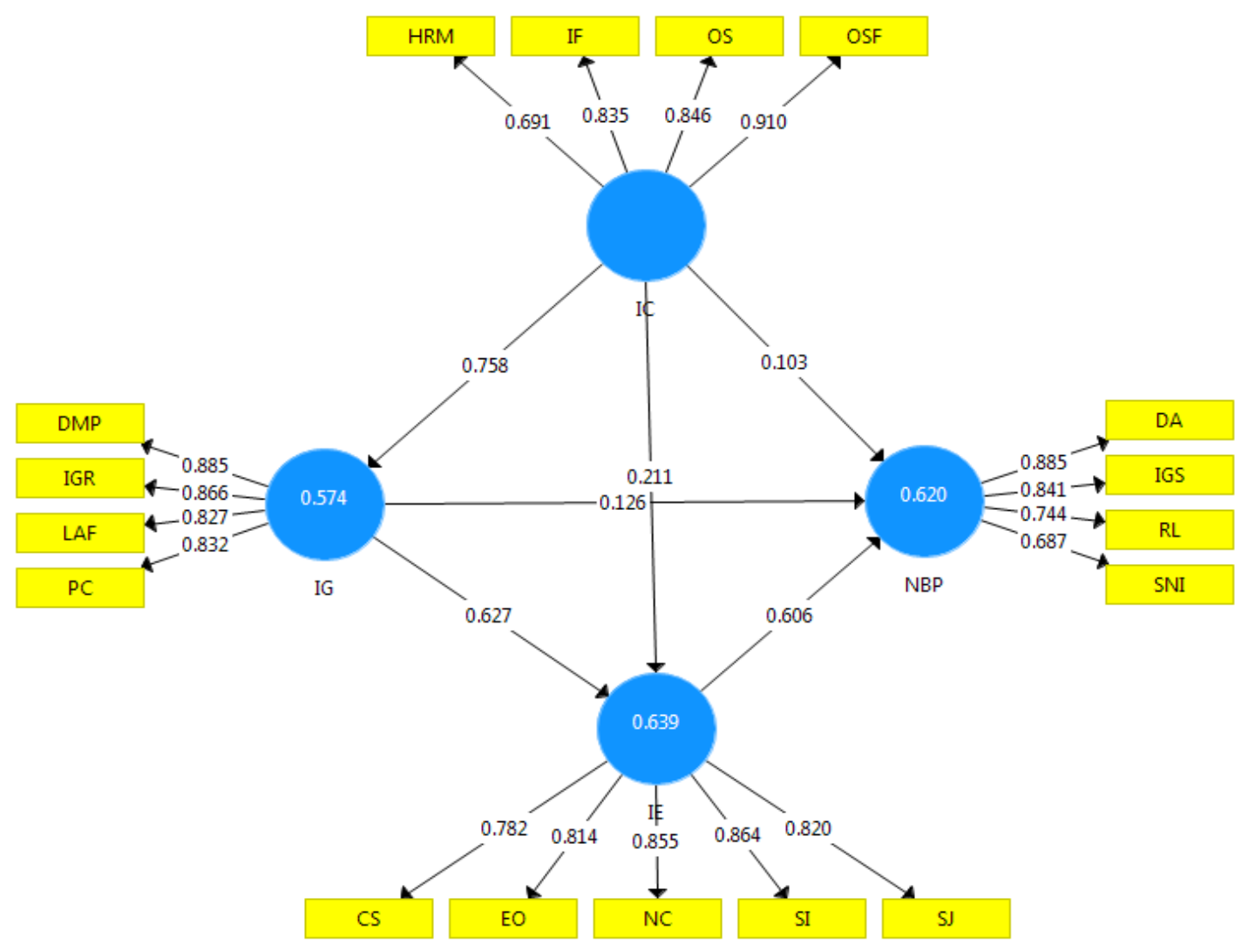

Figure 1: The Empirical Model Depicting the Impacts of Institutional Capacity, Infrastructure Governance and Equity on Nation-Building Process in Ethiopia.

Legend:

$>$ IC=Institutional Capacity which includes (HRM) Human Resource Management; (OR) Organizational Structure; (OSF) Organizational Systems and Frameworks; and, (IF) Infrastructure Funding)

$>\quad$ IG = Infrastructure Governance comprises indicators like (IGR) Intergovernmental Relations; (DMP) Decision Making procedures; (LAF) Land Acquisition Framework; and, Political Commitment (PC)

$>\quad$ IE=Infrastructure Equity embraces factors like (EO) Equal Opportunity; (SJ) Social Justice; (NC) National Competitiveness; (SI) Spatial Intervention; and, (CS)Citizen Satisfaction)

$>\quad$ NBP= Nation-Building process includes (RL) Rule of Law; (DA) Democratic Accountability; (SNI) Shared National Identity; and (IGS) Inclusive Growth and Sustainability

*(Source: Adopted from (Desalegn \& Solomon, 2021),( https://doi.org/10.1007/s11115-021-00523-7.)

Therefore, the paper relies on such empirical evidences just to specify the depth of analysis of the data. It is committed to only objective considerations. Overall, the above outcomes showed that the internal factors have high effects of infrastructure equity on state-andnation-building processes in Ethiopia. Thus, a lack of appropriate HRM, facilitating organizational structure, organizational systems, and framework, and funding of infrastructure is the result of inadequate institutional capacity of the infrastructure sector in Ethiopia. Likewise, a lack of intergovernmental relations (IGR), decision-making process, land-acquisition 
framework, and political commitment is the result of a lack of infrastructure governance in the infrastructure sector in Ethiopia. Furthermore, the shortages of giving equal opportunity, ensuring social justice, national/regional infrastructure competitiveness, spatial intervention, and public satisfaction of the infrastructure sector are also the result of unbalanced infrastructure allocation across regional states in Ethiopia. Equally, a lack of rule of law, democratic/public accountability, shared national identity, and inclusive growths and sustainability are also the result of the deficient nation-building process of the country. Subsequently, the quantitative analysis confirmed that the organizational systems and frameworks with a loading factor of 0.910 are the largest factor that recommends a system a paradigm shift in infrastructure development in Ethiopia (see Table 2 above).

\section{Determining Factor}

Primarily 120 Likert scale questions were formulated based on the literature review. Thus, to avoid an excessive number of variability and unstable estimates in the analysis, only variables that have reached a p-value of less than 0.05 are taken into consideration in the next analyses. So, according to the first step of the analysis result of this paper, the risk factors found to be significantly related to state-and-nation-building processes in Ethiopia. As the outcome elaborates institutional capacity, infrastructure equity, and infrastructure governance are identified factors that show a significant association with stateand-nation-building processes in Ethiopia $(\mathrm{P}<0.05)$.

Next step is running a multiple linear regression model based on the selected factors. For the regressing of these factors, the paper has used the enter method, which is the default procedure available in SPSS. Primarily, outliers, normality, multicollinearity among independent variables, and heteroscedasticity are checked through Cook's distance, Kolmogorov-Smirnov test, and Variance Inflation Factor (VIF). As the result indicates, the minimum Cook's result for the minimum is zero while the maximum is 0.435 ; i.e., the result is less than one. So, there is not detected any outliers which affect the analysis. The Kolmogorov-Smirnov test is also confirmed that the entire variables are linearly associated with each other.

Likewise, the multicollinearity problem is not presented in the analysis because the VIF of the highest and the lowest value lies between 2.397 and 3.361, which is less than 10 (Field \& Golubitsky, 2009). So, there is no strong relationship between explanatory variables. In addition, the distribution is not suffered by heteroscedasticity problems; because the test confirmed this, and the error term distributed normally with mean zero and variance one. So, the estimated regression model presented in the table below provides a more comprehensive and accurate examination of the issued variables. From the bases, the sign of all independent variables beta coefficient (ß) indicates a +ve sign; i.e., any increments of the independent variables lead to an increase in the dependent counterpart. As shown in Table 4 below, all of the indicators of VIF values are less than 5 and their tolerance values are more than 0.2 , there is no collinearity problem.

For instance, the study desires to check whether Institutional Capacity is statistically significant to the determinant of the NationBuilding Process of Ethiopia or not. Hence, Institutional Capacity is significantly vital to determine the Nation-Building Process (Beta= $0.109, \mathrm{P}$ value $=0.001<$ sig. value $=0.05)$, i.e. after taking the remaining effect as a constant, for a unit percentage increment of Institutional Capacity of the country, would lead to $10.9 \%$ increment in the Nation- Building Process. Similarly, the study desires to test here that whether the Infrastructure Governance of Ethiopia has a vital impact on state-and-nationbuilding processes or not. As the result indicated, of course those two variables significantly associated to each other (Beta= $0.125, \mathrm{P}$ value $=0.001<$ sig. value $=0.05)$. This compels that taking the remaining effect as a 
constant, for a unit percentage change of Infrastructure Governance effect would lead to a $12.5 \%$ increment in the nation-building process in Ethiopia.

Finally, this study desires to test whether the equity of infrastructure has a noteworthy impact on the state-and-nation-building process of Ethiopia or not. The result of the study also revealed in the Table below that this domain has a statistically significant contribution to the Nation Building Process (Beta= 0.592, P-value $=0.000<$ sig. value $=0.05)$. Thus, a unit percentage change of Infrastructure Equity would lead to a $59.2 \%$ increment on nationbuilding processes* in Ethiopia, taking remaining effect as constant. Data in Table 4 reavel tolerance value and VIF for composite independent variables.

Table 4. Tolerance Value and VIF for Composite Independent Variables

\begin{tabular}{|c|c|c|c|c|c|c|c|}
\hline \multirow[t]{2}{*}{ Independent Variables/Constructs } & \multicolumn{2}{|c|}{$\begin{array}{c}\text { Unstandardized- } \\
\text { Coefficients }\end{array}$} & \multirow{2}{*}{$\begin{array}{c}\begin{array}{c}\text { Standardize- } \\
\text { Coefficients }\end{array} \\
\text { Beta }\end{array}$} & \multirow[t]{2}{*}{$\begin{array}{c}\mathbf{T} \\
\text { statistics }\end{array}$} & \multirow[t]{2}{*}{ Sig. } & \multicolumn{2}{|c|}{$\begin{array}{c}\text { Collinearity } \\
\text { Statistics } \\
\end{array}$} \\
\hline & B & $\begin{array}{c}\text { Std. } \\
\text { Error }\end{array}$ & & & & $\begin{array}{c}\text { Tolera } \\
\text { nce }\end{array}$ & VIF \\
\hline $\begin{array}{l}\text { (Constant) } \\
\text { institutional capacity in Ethiopian } \\
\text { Infrastructure Governance in } \\
\text { Ethiopia } \\
\text { Infrastructure Equity in Ethiopia }\end{array}$ & $\begin{array}{l}.881 \\
.103 \\
.107\end{array}$ & $\begin{array}{l}.077 \\
.031 \\
.033\end{array}$ & $\begin{array}{l}.109 \\
.125\end{array}$ & $\begin{array}{c}11.417 \\
3.340 \\
3.249\end{array}$ & $\begin{array}{l}.000 \\
.001 \\
.001 \\
.000\end{array}$ & $\begin{array}{l}.417 \\
.298\end{array}$ & $\begin{array}{l}2.396 \\
3.361 \\
2.747\end{array}$ \\
\hline
\end{tabular}

* Dependent Variable: Nation-Building Process in Ethiopia

*(Source: Own data, 2019)

\section{Interviews and Discussions}

After questionnaire survey had been done with results, In-depth interviews and FGDs were accompanied. Interviews and FGDs were engaged from August to November 2019. Grounded on survey results, the interviewees were primarily inquired to elucidate why institutional capacity, infrastructure governance and equity variables impact the state-and-nationbuilding processes, and how to include them to enhance equity of funded infrastructure investment in Ethiopia. Thus, interviews integrated with survey results and their relations with kinds of literature are discussed in the following sections.

All the 18 interviewees believed that capacity, governance, and infrastructure equity have great impacts on state-and-nation-building processes in Ethiopia. They also believed that institutional capacity is the base for the nationbuilding process in any country. This is because infrastructure cannot be fulfilled without a strong institutional capacity (Team, 2011).

However, $11 \%$ believed that, in the previous years, the institutions in the infrastructure sector has contributed a great role in the nationbuilding process as they performed based on government policies and systems. Whereas, $89 \%$ of the interviewees described that institutional capacity has been wrongly implemented for the last three decades due to the interference of corrupt politicians in every institution. Moreover, $89 \%$ of the informants believed that the institutions are not led by professionals rather they were led by political assignees based on political loyalty. Hence, the results of the collaboration are varied, they are not always easy to grip, they often lack clear measures for evaluating them and they give rise to disagreements. In addition, all the four FGDs have similar observations about institutional 
capacity with the majority of interviewees, and also the investigator.

Generally, all interviewees believed that there is a lack of infrastructure governance which is very essential for national consensus and nation-building process in Ethiopia. They emphasized that the role of governance in contributing to bring about trust in state-society relations is very weak. They also stated that civil society is not strong in the sector. Therefore, further reform and attitude changes are needed, and how there could be a strong case for building a national consensus for enhanced stakeholder stewardship through infrastructure (Bowditch \& Noble). All FGDs also believed that, similar to interviewees including the investigator, there is an infrastructure governance problem in Ethiopia.

Regarding infrastructure equity, $89 \%$ of interviewees do believe that there is no infrastructure equity in Ethiopia. This is related to equity theory (Adams, 1963) that proposed individuals who recognize themselves as either "under rewarded or over-rewarded" will experience pain and this pain leads to determinations to reestablish fairness (Huseman et al., 1987). Hence, there is a struggle among elites to restore infrastructure equity in Ethiopia. This is because investment in infrastructure plays a decisive role in encouraging economic development and thus contributes to the decrease of economic inequality and poverty in Ethiopia. Therefore, this needs that coordination and collaborations across infrastructure sectors, across regions, and across jurisdictions are indispensable for aggressive regional equity agenda (Blackwell \& Fox, 2006; Gerber \& Loh, 2015). Similarly, the FGDs have similar results about infrastructure equity with the majority $(89 \%)$ of the interviewees, and also the investigator. They also stressed that, in the previous years, infrastructures are allocated based on political interference without any clear criteria in the country.

All interviewees and FGDs believed that infrastructure has a tangible consequence on the state-and-nation-building processes, and infrastructure improves the citizen's lifestyle. However, currently, as regionalism/provincialism/ becomes a primary interest, it seems unlikely to give priority for the nation-building process in Ethiopia. That is why political strength/ peace, stability, and security/ is a desirable ambition of Ethiopians nowadays (Salih et al., 2018). This is also because a deficiency of housing of diversity might lead to clashes, and pose risk for unification, mainly, multiethnic federal systems in Ethiopia (Mengie, 2016). Moreover, equal access to infrastructure services and a policy environment that does not discriminate against certain location(s), ethnic groups/regions is a central ingredient of structural change (Kedir, 2014).

Finally, according to Elazar (Elazar, 1994) to reach that fulfillment of the promise, the government must address: "people's minds; their cultures; and, their institutions-one of the most promising vehicles to addressing all three is the federal idea" (p. 5). The three central elements of the successful state-and-nationbuilding processes are, closely interlinked in most cases, a unifying and persuasive/integrative ideology, integration of society, and a functional state apparatus (Stone \& Hippler, 2005). Therefore, it is likely to conclude that state-andnation-building processes remain as the primary interest in Ethiopia.

\section{The Implications of Findings}

The paper has delivered some insights into the effects of capacity, governance, and equity on state-and nation-building processes, especially the factors that drive from federal, regional states, and civil society \& bi-and multilateral groups. Analyzing the data (both quantitative and qualitative) collected, this paper showed that the equitable of public infrastructure investments is falling/disrupting, and is negatively affecting the state- nation-building processes in Ethiopia. Specifically, this paper indicated that four constructs are key to the existing distribution of public infrastructure in Ethiopia. Among these constructs, the 
Management Theory and Studies for Rural Business and Infrastructure Development

eISSN 2345-0355. 2021. Vol. 43. No. 4: 484-499

Article DOI: https://doi.org/10.15544/mts.2021.44

institutional capacity and infrastructure governance of the government are at the root causes of inequitable allocation of public infrastructure which also affects nation-building processes. Understanding these issues will help to enhance institutional capacity and good governance, and then for a unit percentage change of Infrastructure Equity would lead to a $59.2 \%$ increment on nation-building process in Ethiopia.

It has to be also understood that infrastructure distribution is becoming increasingly more complex and complicated. Especially, citizen's contact proliferates and grows more unstructured through, for example, social media, and digitally-based information delivery which leads to political instability in the country. Equally important, so extensive as the unfulfilled demand for infrastructure happens, it remains a main constraint on doing business in most African nations which reduces firms' productivity by approximately $40 \%$ (Bank, 2013). To meet a large demand for infrastructure, enhancing infrastructure development is highly fortified, and should be equitably allocated across regional states in Ethiopia. Besides, provision of infrastructure construction is also used by the Ethiopian government as an instrument for employment opportunity, augmented work for home-grown firms, and accordingly insufficiency reduction and economic development. Nevertheless, accurate evidence has revealed that these growth goals may not be appreciated as anticipated due to the high regional disparity in infrastructure distribution and the quality of managing the public infrastructure developments.

Moreover, various researches have established that high regional disparity in infrastructure distribution and quality of public infrastructure investments could be characterized by lack of proper and participatory planning and policy-making processes (Ansar et al., 2016; Dang \& Pheng, 2015). In relation to these, there are issues about the carrying out of infrastructure growth plans that can distress the equity of public infrastructure investments such as corruption and maladministration. The above analysis highlights significance of conveying the issues in both forecasting/planning and operation processes together and inspecting them through government roles as collaborator, director, and implementer of inclusive economic growth.

\section{Conclusion}

This paper confirmed that there is infrastructure inequity in the nation-building process of Ethiopia. This is mainly due to the coordination failure of the government. Thus, the federal government should give corrective measures for the unfair distribution of infrastructure. The paper has also examined infrastructure opportunity and equity that brings a number of plans and policies with the potential for connecting to-employ job seekers, and lowincome inhabitants to temporary and permanent job opportunities. All citizens/stakeholders/regional states need to be authorized to know and comprehend their rights to objectivity, access, service quality, fairness, and compensation for defective and/or nonperformance in the infrastructure prospects. Infrastructure development is a complex process that involves interrelationships. More importantly, the Ethiopian government should develop inclusive and systematic measures that monitor the suitable policy-making steps and process as well as identifying and investigating problems and suggested solutions, setting priorities based on evidence, expressing draft policies, communicating the key-stakeholders to test the validity of draft policies and principles, revising, articulating, and then implementing and evaluating them. Hence, in order to distribute fair infrastructure for every regional state, federal and regional governments, stakeholders, policymakers, financiers, and other related bodies should participate in 
planning, controlling, execution, and process in order to achieve the planned objective and the nation-building process.

Moreover, citizens, civil society, and the private sector must actively participate in the infrastructure allocations in Ethiopia. There should also be national development council that functions as a forum for negotiating over fiveyear plan provisions across regional states in
Ethiopia. In long term, infrastructure equity process necessitates changes in policies to accommodate new evolving trends and factors. Besides, infrastructure development history has verified concentrating on one single factor alone cannot ensure achievement in infrastructure equity processes. Therefore, the way forward is not an easy task and scope for enhancing public infrastructure allocation in Ethiopia is huge.

\section{References}

Act, G. V. (2011). Capacity Building for Organizational Effectiveness. In.

Adams, J. S. (1963). Towards an understanding of inequity. The journal of abnormal and social psychology, 67(5), 422.

Afthanorhan, W. (2013). A comparison of partial least square structural equation modeling (PLS-SEM) and covariance based structural equation modeling (CB-SEM) for confirmatory factor analysis. International Journal of Engineering Science and Innovative Technology, 2(5), 198-205.

Alesina, A. F., \& Reich, B. (2015). Nation building.

Anderson, E., \& O’Neil, T. (2006). A new equity agenda. Reflections on the.

Ansar, A., Flyvbjerg, B., Budzier, A., \& Lunn, D. (2016). Does infrastructure investment lead to economic growth or economic fragility? Evidence from China. Oxford Review of Economic Policy, 32(3), 360-390.

Awang, Z. (2015). SEM made simple: A gentle approach to learning Structural Equation Modeling. MPWS Rich Publication.

Bagozzi, R. P., \& Yi, Y. (1988). On the evaluation of structural equation models. Journal of the academy of marketing science, 16(1), 74-94.

Bank, W. (2013). Fact Sheet: Infrastructure in Sub-Saharan Africa. In: The World Bank Group.

Bhagavan, M. R., \& Virgin, I. (2004). Generic aspects of institutional capacity development in developing countries. Stockholm Environment Institute Stockholm, Sweden.

Blackwell, A. G., \& Fox, R. (2006). Regional equity and smart growth: Opportunities for advancing social and economic justice in America. Urban sprawl a comprehensive reference guide, 407-427.

Bonett, D. G., \& Wright, T. A. (2015). Cronbach's alpha reliability: Interval estimation, hypothesis testing, and sample size planning. Journal of organizational behavior, 36(1), 3-15.

Bowditch, G., \& Noble, G. Building a national consensus: why customer stewardship matters.

Castells, A., \& Solé-Ollé, A. (2005). The regional allocation of infrastructure investment: The role of equity, efficiency and political factors. European Economic Review, 49(5), 1165-1205.

Chotia, V., \& Rao, N. (2015). Examining the interlinkages between regional infrastructure disparities, economic growth, and poverty: A case of Indian States. Economic Annals, 60(205), 53-71.

Cooper, R., \& John, A. (1988). Coordinating coordination failures in Keynesian models. The Quarterly Journal of Economics, 103(3), 441-463.

CRESWELL, J. (1998). Qualitative Inquiry and Research Design. Choosing Among Five Traditions.

Cronbach, L. J. (1951). Coefficient alpha and the internal structure of tests. psychometrika, 16(3), $297-334$.

Dang, G., \& Pheng, L. S. (2015). Infrastructure investments in developing economies. Springer Science Business Media Singapore. DOI, 10, 978-981.

Desalegn, A., \& Solomon, N. (2021). The Interrelationship among Institutional Capacity, Infrastructure Governance and Equity, and Nation-Building Process in Ethiopia. Public Organization Review, 1-21.

Dinnen, S. (2006). Nation-Building Concepts Paper. Draft paper for AusAID.

Elazar, D. J. (1994). Federalism and the Way to Peace. Institute of Intergovernmental Relations, Queen's University Kingston.

Field, M., \& Golubitsky, M. (2009). Symmetry in chaos: a search for pattern in mathematics, art, and nature. SIAM.

Fincham, J. E. (2008). Response rates and responsiveness for surveys, standards, and the Journal. American journal of pharmaceutical education, 72(2).

Fiseha, A. (2006). Federalism and the accommodation of diversity in Ethiopia: A comparative study. Wolf Legal. 


\section{sciendo}

\section{Management Theory and Studies for Rural Business and Infrastructure Development}

eISSN 2345-0355. 2021. Vol. 43. No. 4: 484-499

Article DOI: https://doi.org/10.15544/mts.2021.44

Gerber, E. R., \& Loh, C. G. (2015). Spatial dynamics of vertical and horizontal intergovernmental collaboration. Journal of Urban Affairs, 37(3), 270-288.

Gurara, D., Klyuev, M. V., Mwase, M., Presbitero, A., Xu, X. C., \& Bannister, M. G. J. (2017). Trends and challenges in infrastructure investment in low-income developing countries. International Monetary Fund.

Hair, J. F., Sarstedt, M., Ringle, C. M., \& Mena, J. A. (2012). An assessment of the use of partial least squares structural equation modeling in marketing research. Journal of the academy of marketing science, 40(3), 414-433.

Hair Jr, J. F., Hult, G. T. M., Ringle, C., \& Sarstedt, M. (2016). A Primer on Partial Least Squares Structural Equation Modeling (PLS-SEM). SAGE Publications.

Hair Jr, J. F., Sarstedt, M., Hopkins, L., \& Kuppelwieser, V. G. (2014). Partial least squares structural equation modeling (PLS-SEM): An emerging tool in business research. European business review.

Hawkins, J. N., Jacob, W. J., \& Wenli, L. (2008). Higher education in China: Access, equity and equality. In Inequality in Education (pp. 215-239). Springer.

Hoglund, K., \& Oberg, M. (2011). In-depth Interviewing: The process, skill and ethics of interviews in peace research KAREN BROUNÉUS. In Understanding Peace Research (pp. 142-157). Routledge.

Hulland, J. (1999). Use of partial least squares (PLS) in strategic management research: A review of four recent studies. Strategic management journal, 20(2), 195-204.

Huseman, R. C., Hatfield, J. D., \& Miles, E. W. (1987). A new perspective on equity theory: The equity sensitivity construct. Academy of management Review, 12(2), 222-234.

Kaso, K. A., Aimimtham, S., Saiyasopon, S., \& Chaiphar, W. (2018). Integrated regional development policy formulation in Ethiopia. J. Pol. \& L., 11, 153.

Kedir, A. M. (2014). Inclusive growth and inequalities in the context of structural transformation: Evidence from Ethiopia. Development, 57(3), 512-520.

Kothari, C. (1991). Research Methodology Methods and Techniques. In: New Age International (P) Ltd.

Krueger, R., \& Casey, M. A. (2002). Focus group interviewing on the telephone. In: Minneapolis, MN: State Health Access Data Assistance Center (SHADAC ....

Linz, J. J. (1993). State building and nation building. European Review, 1(4), 355-369.

Malterud, K., Siersma, V. D., \& Guassora, A. D. (2016). Sample size in qualitative interview studies: guided by information power. Qualitative health research, 26(13), 1753-1760.

Mengie, L. T. (2016). Federalism as an Instrument for Unity and the Protection of Minorities: A Comparative Overview: Ethiopia, India and the US. Mizan Law Review, 10(2), 265-295.

Mertens, D. (2015). Research and evaluation in education and psychology: Integrating diversity with qual, quant and mixed methods. In: Thousand Oaks, CA: Sage.

Morgan, D. L. (1997). Planning and research design for focus groups. Focus groups as qualitative research, 16.

Narkhede, P. A., \& Joshi, S. P. (2007). Challenges of human resource management in borderless world. Global Journal of Management Science, 2, 167-173.

OECD. (2015). Towards a Framework for the Governance of Infrastructure. In: OECD Paris.

OECD., G. (2016). Government at a Glance. Organization For Economic.

Okoh, A. S., \& Ebi, B. O. (2013). Infrastructure investment, institutional quality, and economic growth in Nigeria: An interactive approach. European Journal of Humanities and Social Sciences, 26(1).

Oyedele, O. A. (2012). The challenges of infrastructure development in democratic governance. Constructive Economics and Management, 1(6119), 1-15.

Pandey, S. C., \& Patnaik, S. (2014). Establishing reliability and validity in qualitative inquiry: A critical examination. Jharkhand journal of development and management studies, 12(1), 5743-5753.

Patel, V. (2015). Exploratory Factor Analysis: Using SPSS. Workshop: National Level Two Week Faculty Development Programme on Advanced Data Analysis for Business Research Using Statistical Packages. Washington, DC: Georgetown University, Rammelt, C. (2018). Infrastructures as catalysts: Precipitating uneven patterns of development from large-scale infrastructure investments. Sustainability, 10(4), 1286.

Saldivar, M. (2012). A primer on survey response rate. Florida State University: Learning Systems Institute.

Salih, M., Eshete, A., \& Assefa, S. (2018). Reflections on Expanding Ethiopia's Democratic Space: Aspirations, Opportunities, Choices. Friedrich Ebert Stiftung Addis Ababa Office.

Schultz, D. (2017). Regional disparities in economic development: lessons learned from the United States of America. Вестник Российского университета дружбы народов. Серия: Государственное и муниципальное управление, 4(2).

Shiferaw, A. (2017). Productive capacity and economic growth in Ethiopia. United Nations, Department of Economics and Social Affairs. 
Stepan, A., Linz, J. J., \& Yadav, Y. (2011). Crafting state-nations: India and other multinational democracies. JHU Press.

Stone, B., \& Hippler, J. (2005). Nation-building: a key concept for peaceful conflict transformation. Pluto Press (UK). Tavakol, M., \& Dennick, R. (2011). Making sense of Cronbach's alpha. International journal of medical education, 2, 53.

Team, T. (2011). AFRICAN DEVELOPMENT BANK AFRICAN DEVELOPMENT FUND.

Van de Walle, S., \& Scott, Z. (2009). The role of public services in state-and nation building: Exploring lessons from European history for fragile states.

Von Bogdandy, A., Häußler, S., Hanschmann, F., \& Utz, R. (2005). State-building, nation-building, and constitutional politics in post-conflict situations: Conceptual clarifications and an appraisal of different approaches. Max Planck Yearbook of United Nations Law Online, 9(1), 579-613.

Walter, I. (2016). The infrastructure finance challenge. Available at SSRN 2841281.

Zhang, X., \& Fan, S. (2002). Infrastructure, openness, and regional inequality in India. 